ISSN:2528-9527

E-ISSN : 2528-9535

YIl Year: 7

Cilt Volume:7

Sayı Issue : 12

Uluslararası Toplum Araştırmaları Dergisi

International Journal of Society Researches

Haziran June 2017

Makalenin Geliș Tarihi Received Date: 02/06/2017

Makalenin Kabul Tarihi Accepted Date: 22/06/2017

\title{
Milli Mücadele Döneminde Konya ve Atatürk
}

\author{
Yaşar Semiz ${ }^{*}$ Güngör Toplu*
}

* Prof. Dr., Selcuk Üniversitesi, Sosyal Bilimler Meslek Yüksekokulu, Konya/ Türkiye

E-Posta:ysemiz@selcuk.edu.tr

ORCID: 0000-0002-9204-8014

* Okutman., Selcuk Üniversitesi, Atatürk İlkeleri ve İnkılâp Tarihi Bölümü, Konya/ Türkiye

E-Posta:gtoplu@selcuk.edu.tr

ORCID: 0000-0002-0511-3528

\section{Öz}

Milli Mücadele yıllarında stratejik öneminden dolayı, daha sonraki yıllarda ise gelişen olaylara karşı Türkiye genelini en iyi yansıtan yerlerden birisi Konya'dır. Bu itibarla Gazi Mustafa Kemal Atatürk hem Milli mücadele yillarında hem de Cumhuriyet döneminde her önemli sosyal ya da siyasi olaym ardından Konya'ya gelmiş, şehirde halkla iç içe olarak halkın nabzını tutmuştur.Atatürk'ün Konya'ya gelişleri ile siyasi ve sosyal olayları yan yana getirdiğimiz zaman bu hakikat daha iyi anlaşılmaktır. Bu çalışma iki bölümden oluşmaktadır. Çalışmanın giriş kısmında Konya'nın 1900-1920 yıllarında sosyal, ekonomik ve stratejik açıdan kısa bir değerlendirmesi yapıldıktan sonra birinci bölüme geçilecektir.Birinci bölümde Millî Mücadele açısından Konya'nın yeri ve öneminden bahsedilecektir. İlk olarakKonya'da işgalci devletlerin, İstanbul Hükümeti'nin, azınlıklarm faaliyetleri değerlendirilecek ve halkın gelişmelere yaklaşımı ele alınacaktır. Ardından Müdafaa-i Hukuk Cemiyeti'nin kuruluşu ele alınacak, Millî Mücadeleye geç katılmasının sebepleri sorgulanacak ve milli teşkilatların kurulması sırasında karşılaşılan güçlükler üzerinde durulduktan sonra Konya'nın tam olarak milli mücadele saflarına katılı̧sü̈reci ele alınacaktır. İkinci bölümde ise Atatürk'ün Millı̂ Mücadele yıllarında Konya'ya yaptığ $ı$ ziyaretleri değerlendirilecektir.

Anahtar Kelimeler: Millî Mücadele, Atatürk, Konya, Ziyaret, Halk 
ISSN:2528-9527

E-ISSN : 2528-9535

YIl Year: 7

Cilt Volume:7

Sayı Issue :12

Uluslararası Toplum Araştırmaları Dergisi

International Journal of Society Researches

HaziranJune 2017

Makalenin Geliş Tarihi Received Date: 02/06/2017

Makalenin Kabul Tarihi Accepted Date: 22/06/2017

\title{
Konya and Atatürk During the National Struggle
}

\begin{abstract}
Due to its strategic importance in the years of the National Struggle, and in the following years regarding the developing events, Konya is one of the places that best reflects the general of Turkey. In this respect, Gazi Mustafa Kemal Atatürk came to Konya after every major social or political event in both the national struggle years and the Republic Period; he kept the pulse of the people in the city with being very close to them. This truth is to be understood better when we bring the political and social events together with Ataturk's coming to Konya. This study consists of two parts. We will go into the first part after a brief evaluation of Konya in the introduction part of the study, in terms of social, economic and strategic in the years 1900-1920. In the first chapter, the place and the importance of Konya will be mentioned regarding National Struggle. Firstly, the activities of the occupant states, Istanbul government and minorities in Konya will be evaluated and the public's approach to developments will be discussed. Then the establishment of the Defence of Rights Society will be dealt with, the reasons for the late participation in the National Struggle will be questioned and after focusing on the difficulties encountered during the establishment of the national organizations, the precise joining process of Konya in the national struggles will be dealt with. In the second part, visits of Atatürk to Konya during the years of national struggle will be evaluated.
\end{abstract}

Key Words: Independence War, Atatürk, Konya Visit, Nation 


\section{Giriş}

Yirminci yüzyılın başında Konya idari bakımdan, günümüzde ayrı ayrı vilayet olan; Niğde, Isparta, Burdur ve Antalya sancaklarını bünyesinde bulunduran bir vilayetti (Nasrallah, Rüştüve Eşref,1325, s.27-30). 19061907 nüfus sayımına görebugünkü Konya hudutları içerisinde toplam nüfusun 145.713'ü (\%91.47) Müslüman; 8.664'ü (\%6.93) Rum; 1.558'i (\%1.25) Ermeni; 262'si (\%0.02) Yahudi idi(Karpat, 1985, s.162-169).Hicri 1317 tarihli Konya Salnamesine göre Konya il merkezinde toplam nüfusun 41.929'u Müslüman; 1852'si Ermeni;1054'ü Rum; milliyeti tespit edilmeyen 27 Katolik, 22 de Protestan vardı (Konya Vilayet Salnamesi, 1317, s. 22).

Vilayetin ticaret ve memuriyet hayatında Müslümanlar gibi gayrimüslimlerinde önemli yeri vardı.Özellikle demiryolu işletmeleri, habercilik ve bankacılık sahalarında çok sayıda gayrimüslim çalışıyordu (Gürel, 1989,s.22-23). Ulaşım ve haberleşme dili ise Fransızca idi.Aynı şekilde Konya' da bazı şirketlerinde şubeleri vardı. Bunlar arasında en önemli olanlardan biri Alman asıllı Herzekir tarafından açılan Anadolu Sanayi ve Ticaret Şirketi'dir (Babalık, 26 Ağustos 1331).

Diğer taraftan Konya tarım ve hayvancılığa dayalı üretim kapasitesi ile yerli ve yabancıların yakından ilgilendiği bir yerdi.Iç piyasada çevre illerin yanı sıra İstanbul'un da tahıl ihtiyacının önemli bir kısmı Konya' dan karşılanıyordu.

Konya, 1906'dan beri İstanbul'u Bağdat'a bağlayan demir yollarının kavşak noktasıdır. Şehrin tarihsel dokusunun yanı sıra çevresinde bulundurduğu yeraltı ve yerüstü zenginlikleri ile yerli ve yabancı pek çok yatırımcı için özel bir konuma sahiptir. Bu nedenlerden dolayı Demiryolunun Konya'ya ulaşması, Konya'nın önemli şehir ve limanlara ulaşımını kolaylaştırırken, haberleşme sisteminin gelişmesine de katkı sağladı.Bu cümleden olarak Konya, merkez kaza ve nahiyeleri arasında telgraf hattına sahip olan nadir vilayetlerden biridir (Babalık,6 Temmuz 1920).

İşte bundan dolayıdır ki Millî Mücadele'nin ilk günlerinden itibaren hem işgal kuvvetleri ve İstanbul Hükümeti hemde Ankara Hükûmeti, Konya'da ciddi bir hâkimiyetkurma mücadelesi verdi.Mondros Mütarekesi'nden sonra,önce 22 Ocak'ta İngilizler ardından da 24 Nisan'da İtalyanlar tarafından işgal edildi (Bıyıklığlu,1969, s.294). İşgalin azınlıkların 
desteği ve İstanbul Hükümet' inin basiretsizliği yüzünden genişlediği dönemde dengeler işgalciler ve İstanbul Hükûmeti lehineydi. Halk bir taraftan işgalcileri ve onların işbirlikçisi azınlıklardan rahatsızlık duyuyor,diğer taraftan İstanbul Hükümeti'nin idarecileri ve yönlendirdiği din adamlarının Mustafa Kemal Paşa ve arkadaşlarına yönelttiği insafsız eleştirilerden ve karalamalarından dolayı işgalcilere karşı oluşturulan Kuvayı Milliye,Müdafaa-i Hukuk gibi teşkilatlarda yer almakta tereddüt ediyordu.

Bu çalışmada Konya'nın Milli Mücadeleye geç katılmasının sebepleri, Ankara ve İstanbul Hükümetlerinin Konya'ya verdikleri önem, Konya' nin Milli Mücadele açısından konumu ve Mustafa Kemal Paşa'nin Konya' yı ziyaretleri değerlendirilecektir.

\section{Konya'nın Milli Mücadeleye Geç Katılmasının Sebepleri}

Konya, İstanbul'a ve İzmir'e demiryolu bağlantısı olan bir konuma sahiptir. Milli Mücadele yıllarında Batı Cephesinin ikmal merkezidir. Aynı zamanda ürettiği tarım ürünleri açızından ülke ekonomisinde önemli bir yere sahiptir. Bu itibarla Konya hem Milli Mücadele verenler hem de Anadolu'yu işgal etmeye çalışanlar Konya'yı ellerinde tutabilmek için mücadele etmektedir. Bu noktalardan hareketle aşağıda Konya'nın Milli Mücadele'ye geç katılmasının başlıca sebeplerin değerlendirilecektir.

\section{1. İşgalci Devletlerin Faaliyetleri}

Mondros Mütarekesinden sonra Anadolu'yu kendi aralarında paylaşmaya karar veren İtilaf Devletleri'nin öncelikle işgal etmeyi düşündükleri yerlerden biri Konya'dır. Çünkü Konya Anadolu'nun güneyindeki vilayetleri İstanbul'a bağlayan ayrıca batıya da açılabilen önemli bir kavşak noktasıdır. Bu itibarla eğer Anadolu'da hâkimiyet kurulmak isteniyorsa Konya'nın mutlaka elde tutulması gerektiğine inanan İngilizler,mütarekenin hemen ardından Konya'ya kontrol subaylarını gönderdiler. 7 Ocak'ta İtalyanların Konya İstasyonu'nu kontrol etmelerinin ardından 18 Ocak 1335'(1919) da İngilizler mütareke hükümlerini gerekçe göstererek demiryolu hattını kontrol etmeye başladılar (Avanas, 1998, s.29-30). İngilizler Konya'da İtalyanlar gibi uzun süre kalmadılar. 
Ancak Konya'yı Batı ve Güneye asker ve mühimmat sevkiyatı için bir üs olarak kullandılar. İzmir'in işgalinden sonra ise buradaki kuvvetlerinin bir kısmını Afyon üzerinden İzmir'e; bir kısmını da Antalya'ya sevk ettiler ve mütarekeden önce İtalyan imtiyaz sahası olarak belirlenen Konya'dan ayrıldılar (Avanas, 1998, s.29-30). Bununla birlikte kendileri ile işbirliği yapan Hürriyet ve İtilaf Fırkası, Sulh ve Selamet Frrkası, İngiliz Muhipleri gibi cemiyetler aracılığıyla Konya halkı üzerinde etkisini sürdürdü. Propagandanın yanı sıra dağıttığı silah ve paralarla zaman zaman halkı isyana teşvik etti.Bu yüzden Konya'da çıan isyanlarda İngiliz silah ve parasının yanı sıra İngiliz ve İstanbul Hükûmetlerinindesteğindeki bazı din adamlarının etkisi hayli fazladır. Bu durum halkın Millî Mücadele'ye katılması konusundaki tereddütler yaşamasına sebep oldu.

\section{2. İstanbul Hükümeti'nin Faaliyetleri}

Millî Mücadele'nin ilk günlerinde İstanbul Hükûmeti adına Konya' da vali olarak görev yapan Cemal Bey'di (Erdeha, 1975, s.267- 292). Hürriyet ve İtilaf Fırkasıve İngiliz Muhipleri Cemiyeti taraftarı Artın Cemal,Sadrazam Damat Ferit Paşa tarafından Konya'ya millî faaliyetlerin harekete geçmesini engellemek için görevlendirilmişti (Erdeha, 1975, s.267; Altay, 1970, s.222).Cemal Bey göreve başladığı günden itibaren Kuvayı Milliye hareketini halka, I. Dünya Savaşı'nın ve başarısızlığın sorumlusu olarak gördüğ̈̈ "İttihatçı Hareket" olarak tanıtmaya çalıştı. Bu amaçla Konya halkı üzerinde de ciddi etkisi bulunan başta Sait Molla,Papaz Frew, Şeyh Zeynel Abidin Hoca gibi din adamları ve eşraftan destek alarak halkı Kuvayı Milliye aleyhine kışkırttı (Erdeha, 1975, s.275;Avanas, 1998, s. 101104; M. Sıfır, Yeni Sabah, 1940; Göztepe, 1969, s.79-82).

Vali Cemal Bey'in Kuvayı Milliye aleyhindeki bir diğer faaliyeti ise 12.Kolordu'ya mensup subay ve askerler arasında propaganda yaptırdı. Onları Saltanat'a itaat etmeye ve işgallere karşı direnmenin Dine, Saltanatın ve Hükümetin imzaladığı mütarekeye itaatsizlik olacağını anlatarak askerlikten soğutmaya çalıştı. Bu cümleden olarak hükümetin mütareke ile birlikte askerlerin terhisi kararı aldığını ilan ederek bu karara uymayanları "hükûmete isyan" suçundan tutuklatıp hapse attıracağını yaydı(Avanas, (t.y.) s.27). 
Yine İstanbul Hükümeti'nin desteği ve Vali Cemal Bey' in himayesinde kurulan Teali-i İslam Cemiyeti, Konya' da açtığı okullar vasıtasıyla halkın yanı sıra ordu mensupları arasında da faaliyet göstermeye başladı. Yaptığ propagandalarla askerler arasında da taraftar buldu. Bundan cesaret alan cemiyetin Konya Şubesi Başkanı Ahmet Rüştü Efendi, Kolordu Komutanı Fahrettin Bey'e bir telgraf çekerek okullarına gelmek isteyen askerlerin terhis edilmesini istedi (Avanas,1998, s.63).

\subsection{Halkın İlgisizliği}

Uzun zamandan beri düşman işgali görmemiş Konya' da eşraf tabir edilen halkın önde gelenleri Milli Mücadele'ye karşı ilgisiz,hatta yer yer karşı çıkmaktaydı (Erdeha, 1975, s.266-267; Akandere, (t.y.) s.7).

Fahrettin Altay Paşa "Hacıă̆a ve Efendiler" diye tanımladığı bu zümre hakkında şunları yazar: "Bunlar varlıklı kimseler olup hacı olmuşlar, sakallı başları abani sarıklı, eli tespihli,beş vakit namazını camide kılan, temiz ahlaklı, fakat maddi menfaatlere düşkün basit kimselerdir. Çoğunun birer dükkânı vardır. Küçük ticaret işleri yaparlar. Asıl kazançları ise köylülere bankerliktir. O zamanlar Ziraat Sandığı ve Osmanlı Bankası'ndan başka esashı bankalarımız olmadı̆̆ından, halkın kredi ihtiyacın bu Hacı Ağalar temin ederek bundan kazanç edinirlerdi. Bu kazanca da faiz ismini vermeyerek, haram sayllmayacak şer'i hileler ararlar ve sanatkâr hacı efendilere tabii bulunurlardı. Mahalle imamları ve diğer mensupları medreselerin harçlar bu tabakalardan en samimimi arkadaşlarıdır"( Altay, 1970, s. 220 ).

Bu tabaka, menfaatlerinin bozulmaması için mevcut idarenin istekleri doğrultusunda hareket ederek Saltanat ve Hilafet'e bağlılıklarını bildiriyor ve işgallere karşı direnmeye hazırlanan Kuvayı Milliyecilere sıcak bakmıyorlardı. Bunda yukarıda bahsettiğimiz idareci ve din adamlarının yanı sıra işgalci İtalyanların halka karşı takip ettiği hoşgörülü politikanın da etkisi vardır (Akandere, (t.y.) s. 7).

\subsection{Azınlıkların Faaliyetleri}


Yüzyıllarca Türk ve Müslümanlarla birlikte barış ve huzur içinde yaşayan azınlıklar, Konya'nın İngiliz ve İtalyanlar tarafından işgalinin ardından gerçek kimliklerini ortaya koydular. Mütarekeden önce Konya'da okulları, hastaneleri,kiliseleri,ticari müesseseleri ile Türk ve Müslümanlarla iyi komşuluk içinde yaşarken mütarekeden sonra büyük oranda tavırlarını değiştirdiler. Özellikle Gazialemşah, Çiftemerdiven mahallelerini Yunan Bayrakları ile donattılar (Arabacı, 1991, s.5). Başta hırsızlık, darp gibi pek çok asayişsizlik olaylarına karışmaya başladılar. Vali Cemal Bey ise Müslümanlara karşı işlenen bu tür olayları çoğunlukla işgalcilerle ters düşmemek uğruna kapattı (Arabacı, 1991, s.4 ). Yine azınlıkların bazıları, vatanseverliği ile öne çıkan Konyalıları İttihatçı diye suçlayarak tutuklanmalarına ya da takibata uğramalarını sağladılar.Bu durum da KuvayıMilliye'ye katılımı engelledi.

\section{Konya'da Müdafaa-i Hukuk Cemiyetinin Kuruluşu}

Konya'da Milli Mücadele aleyhtarlarının davranışları gün geçtikçe tahammül edilemez hâle geldi. Bu tahammülsüzlügün doruğa ulaşttğı an Vali Cemal Bey'in Sivas Kongre'sine katılmak isteyen heyeti engellemesi ve ardından da 12 Eylül'de Sivas Kongresinde alınan İstanbul Hükûmeti ile resmî haberleşmenin kesilmesine karşı çıkması, suçluları hapishaneden çıkararak silahlandırması ve işgal kuvvetleri ile işbirliği yapması ile oldu.

Bu arada 17 Nisan 1919'dan itibaren Kolordu Komutanlığı'na atananFahrettin Altay ile millî direnişten yana tavırları ile tanınan Albay Mehmet Selahattin Bey, Vali Cemal Bey'in ısrarlı talepleri üzerine İstanbul Hükûmeti tarafından görevinden alındılar. Yerlerine I. Dünya Savaşı'nda Yemen Kahramanı olarak ün yapan Topal Sait Paşa 12. Kolordu komutanlığına atandı (Altay, 1970, s.182-184). Ancak 11 Eylül 1919 tarihinde görevine başlayan Sait Paşa da Vali Cemal Bey'in bütün baskılarına rağmen Millî Mücadele lehine toplantılar düzenlemeye başladılar. Öğüt ve Babalık gazetelerinde İzmir'in işgalini protesto eden yazılar yayımlattılar (Erdeha, 1975, s.274). Bu gelişmeler olurken Beyşehir Süvari 
Alay Komutan Vekili Kurmay Binbaşı Nazım Bey Konya Valisine iyice cephe ald.

Vali Cemal Bey ise bu tepkilerin Konya'da bulunan ittihatçı subaylar tarafından tertiplendiğini düşünüyor ve bunlar için sürgün listeleri hazırliyordu. Bu sürgün listesinde daha önce görevinden alınan Kolordu Komutanı Fahrettin Altay'ın adı da vardı (Erdeha, 1975, s.274).

Bu konuda Fahrettin Bey'e yapılan tebligat yaşanan şartlar bakımından dikkat çekicidir.

“Dünkü gün başlarında Belediye Reisi olduğu hâlde bir kısım halktan müteşekkil bir heyetin İtalya ve Ingiliz mümessillerine müracaat ederek askerî kumandanlardan altı kişinin Konya'dan 24 saat zarfinda çıkarılmalarını,aksi halde memlekette büyük fenalıklar vukua geleceğini ifade ettiklerini mümessiller tarafindan bildirmiş ve zikredilen heyet yanıma gelerek ayn teklifi ileri sürmüştü.Bu altı kişi meyanında maatteessüfyüksek kişilerin de bulunduğunu tebliğ ve memleketin selameti namina bu gece hareket edecek trenle hareketinizin muvafik olduğu,durum icabı beyan olunur efendim".

12. Kolordu KomutanıFaik Sait (Altay, 1970, s. 188-190).

Nitekim Vali Cemal Bey'in baskılarına daha fazla dayanamayan ve İstanbul Hükümeti tarafından ölü veya diri ele geçirilmek istenen Beyşehir Süvari Alayı Komutan Vekili Binbaşı Nazım Bey, birliği ile birlikte Konya önlerine kadar gelip Vali ve yandaşlarını tehdit etmeye başladı (Altay, 1970, s.189). Nazım Bey'in bu davranışı 12.Kolordu' ya mensup askerler ve baskılardan bıkan şehir halkından da destek buldu. Bu durum Vali Cemal Bey'i korkutmaya yetti. İtalyanların da yardımı ile 25 Eylül 1919 akşamı bir yük treni ile İstanbul'a kaçtı (Avanas, 1998; s. 85 ).

Cemal Bey'in ayrılmasının ardından Konya'da müdafaa-i Hukuk Cemiyeti'nin kuruluş çalışmaları hızlandı. Öncelikle kaçan valinin yerine eşraf, vekâleten Mehmet Vehbi Hoca'yı görevlendirdi (Coşar, 1919, S. 119; Atalay, 1997, s.15). Bu arada Fransız işgali altındaki Adana'dan kaçan bazı KuvayıMilliyeciler Konya'yı kendilerine merkez yapmışlardı. Bunların öncülügünde Konya' da Kuvayı Milliyeçeteleri kurulmaya başladı. 12. Kolordu Komutanlığı bunlara sadece el altından silah yardımı yapıyor fakat subay kadrosu ile açıkça desteklemeye yanaşmıyordu.

Yine Vali Cemal'in kaçışının ardından Konya'da Müdafaa-i Hukuk Teşkilatı'nın kuruluşu da hızlandı. Vali Cemal Bey'in gidişinin ardından Mustafa Kemal Paşa, 30 Eylül 1335 (1919) tarihinde Konya Valiliği'ne 
Müdafaa-i Hukuk teşkilatının kurulması doğrultusunda bir telgraf gönderdi (Atatürk'ün Tamim Telgraf ve Beyannameleri, 1991, s.102).Bu telgrafın ardından Konya'ya gelen Refet Bele'nin gayretleri ile 8 Ekim 1919'da Konya Müdafaa-i Hukuk Cemiyeti kurularak yaklaşık 20 kişilik geçici heyeti seçildi (Kutay, 1977, s.90-91). Bu heyet kendi arasında toplanarak Yalvaçlı Ömer Vehbi Efendi, Müftü zade Cevdet.; Ahi Baba zade Yusuf Ziya, Eczacı Hüsamettin.; Hacı Mehmet zade Süleyman, Tahir Paşazade Cevdet,Kadı zade Ahmet, Hacı Bahri zade Mümtaz Bahri.;Aktariye Şirketi Müdürü Tahir ve Mustafa Şevki Bey'i faal üyeliklere getirdiler (Avanas, 1998, s.65-66; Erdeha, 1975, s.278).

Konya Müdafaa-i Hukuk Cemiyeti'nin kurulmasının ardından Ilgın ve Bozkır teşkilatları da Konya teşkilatına katıldı. Ancak kısa bir süre sonra cemiyet içinde bazı sıkıntılar yaşanmaya başladı. Cemiyete millî mücadele davasında samimi olmayan bazı menfaat perestler de üye olmuştu. Bunların bir kısmı daha önce Vali Cemal Bey'in yanında yer alan kimselerdi. Bazıları ya halktan zorla para topluyor, ya da ticaretle uğraşıyordu. Memur olanlarsa daha fazla maaş alabilmenin mücadelesini veriyorlardı (Altay, 1970, s.222-223). Bu davranışlar vatansever Konyalıları rahatsız ediyordu. Nitekim aralarında Refik(Koraltan) ve Eflatun Cem (Güney)'in de bulunduğu bir grup vatanperver, 12.Kolordu Komutanı Fahrettin (Altay)'a başvurarak Kuvayı Millı̂ye adına işlenen kötülüklerin önlenmesini istediler. Fahrettin Bey vatanperverlerin bu şikâyetlerini Heyet-i Temsiliye Reisi Mustafa Kemal Paşa'ya iletti. Derhal duruma müdahale eden Mustafa Kemal Paşa, Konya Müdafaa-i Hukuk Cemiyeti'nin yeniden düzenlenmesini istedi. Yeniden düzenlenmenin ardından cemiyetin yeni başkanı Sivaslı Ali Kemali oldu(Altay, 1970, s.227; Avanas, 1998, s.68-69). Aynı dönemde yine cemiyet bünyesinde bir irşat ve teftiş heyeti kuruldu(Altay, 1970, s.227).

Ali Kemali Hoca'nın başkanlığa seçilmesi ile birlikte Konya Müdafaa-i Hukuk Cemiyet'i oldukça aktif bir hâle geldi. İlki 8 Ocak 1920' de ${ }^{1}$ olmak üzere Ocak ayı içinde işgaller aleyhine dört miting düzenlendi. Bunların en dikkat çekici olanı işgalci İtalyanların 13 Kânunusani 1336'da (Ocak

\footnotetext{
${ }^{1}$ - Konya'da Issgallere Karşı düzenlenen ilk miting Vali Cemal Bey'in görevde olduğu 12 Eylül 1919'da yapıldı. Bak (Avanas, 1998, s.38; Önder, 1955, s.56). Burada kastedilen ise Ali Kemali'nin Müdafaa-i Hukuk Cemiyeti'nin başına gelmesinden sonraki ilktir.
} 
1920) Öğüt Gazetesi matbaasını basarak gazetenin yayınının durdurulması üzerine düzenlenen dördüncü mitingdir(Önder, 1986,s.8-10).Miting 13 Ocak Cuma günüdür. Cuma Namazı'ndan sonra halk hükümet konağının önünde toplanarak İngilizlerin isteği ile İtalyanların Öğüt Gazetesi'ni kapatmasını şiddetle protesto etti. Mitingin öncüsü Müdafaai Hukuk Başkanı Sivaslı Ali Kemali Hoca'dır. O İtalyan askerlerinin de orada olduğunu bile bile onlara karşı çok sert ifadeler kullanarak(Kişmir, 09 Nisan1968), konuşmasını şöyle sürdürdü: “Ey ahali, ey Konyahlar, gazete demek bir milletin dili demektir, General Miln dilimizi kesti... Bizi susturamazlar. Dönersek kahpeyiz millet yolunda bir azimetten. Bu millet ölmedi, ölmeyecektir. Bu gün Öğüt'ü kapatmışlarsa yarı bir başka Öğ̈̈̈t çıacak"(Coşar, 1964, s.157-159).

Konya ile ilgili pek çok yazısı bulunan Mehmet Önder ise o günün görgü tanıklarından² dinlediklerine dayanarak şu ifadeleri aktardı:“ Ey ahali, Ey Konyahlar gazete demek bir milletin dili demektir. Ne idüğ̈̈ belirsiz birkaç Frenk dilimize kilit vurdu. Milli davalarımızı müdafaa etmek, dilimizi, imanımız Türklü̆̆̈̈müzü muhafaza etmek bizlerin, sizlerin, hepimizin vazifesidir. Bizi susturamazlar. Bu gün Öğ̈üt'ü kapatmışlarsa yarın bir başka Öğüt çıkacak, bizi hak ve hakikat yolunda asla susturamayacaklardır". (Önder, 1954,s.53-55; Önder, 1986, s.12-13)

Gerçektende Öğüt Gazetesi susturulamadı. Aynı kadro 27 Ocak 1920'den itibaren Ögüt yerine Nasihat Gazetesini çıkardı (Önder,1986, s.14-15).Nasihat 23 sayı yayımlandıktan sonra 17 Şubat 1920 'den itibaren yayın hayatına yeniden Öğüt olarak devam etti(Önder, 1986, s.15-16).Bu durumdan rahatsız olan İngilizler, İtalyan komutanına bu hususta daha kararlı hareket etmeleri talebinde bulundu. Ancak İtalyanlar gazetenin kendi bölgelerinin dışında Kuvayı Milliye kontrolünde yayımlanarak şehre sokulduğunu ileri sürerek İngiliz taleplerini geçiştirdi (Coşar, 1964, s.15-160).

\section{Konya'nın Tam Olarak Milli Mücadele Saflarına Katılması}

\footnotetext{
2 - Bu tanıklar Prof. Dr. Sadi Irmak, Av. Tahir Mıhçı ve Memduh Yavuz Süslü’dür.
} 
16 Mart 1920'de İstanbul'un İngilizler tarafından işgalinin ardından Konya' da hangi saflarda yer alınacağı konusunda yeniden tereddütler yaşanmaya başlandı. Dönemin Valisi Suphi Bey ve 12. Kolordu Komutanı Fahrettin Bey ne İstanbul Hükümeti'ni karşısına almak ne de Ankara ile ters düşmek istediğinden bu süreçte her iki taraflada iyi ilişkilerini sürdürmek niyetindeydi. Bu durum doğal olarak Müdafaa-i Hukuk Cemiyeti'ne de yansıyordu. Heyet-i Temsiliye kararı ile işgal altındaki İstanbul'la her türlü haberleşmenin millî menfaatler doğrultusunda yasaklanmış olmasına rağmen Konya Valisi ve Kolordu Komutanı dolaylı da olsa İstanbul Hükümeti ile irtibatını sürdü. Bu isimlerin İşgallerin mütarekeye aykırı olmadığına inanmaları (Erdeha, 1975, s.286; Cebesoy, 1953, s.323-327) Ankara'yı ciddi şekilde rahatsız etti. İstanbul'un işgalinin mütareke şartlarına aykırı olmadığına inanmak,saflı̆̆nötesinde milli mücadele fikrine ters düşen bir durumdu. Nutuk'ta, bu konuya değinilirken duyulan endişe, Heyet-i Temsiliye Kâtibi Hayati'nin ifadeleri ile şu şekilde dile getiriliyor: "İstanbul merkezi, İngiliz resmî tebliğinde Konya Valisinin cevap verdiği yazılıyor. Paşa Hazretleri(Mustafa Kemal) bunun sihhatini anlamak istiyorlar".(Nutuk, C. 3, Belge 257a, 257b., 1973, s.1233)

Mustafa Kemal Paşa ve arkadaşları durumu sadece bilgi edinme noktasında bırakmadı.Ankara'da 20. Kolordu komutanı Ali Fuat Paşa ile baş başa vererek Konya'nın kaybedilmemesi için acil tedbir almaya karar verdiler.

Nitekim Nazilli'de bulunan Refet(Bele) Bey'den yeter bir kuvvetle Konya üzerine yürümesini ve Vali Suphi Bey'le Kolordu Komutanı Fahrettin Bey'i Ankara'ya getirmesini istediler(Cebesoy, 1953, s.325).Albay Refet Bey, Ankara'da toplanacak Millet Meclisi'ne Konya'dan temsilci gönderilmemesinin kararlaştırıldığı, hatta bu meclise karşı protesto mitinglerinin düzenleneceği ve Vali Suphi Bey ile Kolordu Komutanı Fahrettin Bey'in de bu protestolar karşısında pasif davranacakları haberinin yayılması üzerine 26 Mart 1920 de Konya üzerine yürüdü. 3 Nisan 1920 günü erken saatte Konya- Sarayönü'ne geldi(Erdeha, 1975, s.286; Cebesoy, 1953, s. 332; Kişmir, 12 Nisan 1968).Önce haberleşme sistemini kontrol etti. Ardından büyük bir kuvvetle geldiği haberinin yayılmasını sağladı. Kolordu Komutanı Fahrettin Bey ile görüşerek Sarayönü'ne gelmesini, gelirken de başta Vali Suphi Bey olmak üzere Belediye Başkanını, Müftüyü, 
Müdafaa-i Hukuk Cemiyeti yöneticileri ile bunların muhalifi tanınan kimselerin öncülerini ve şehrin ileri gelen eşrafını da beraberinde getirmesiniistedi. Öğleden sonra, önce Fahrettin Bey ardından da Vali Suphi Bey 23 kişilik heyetle Sarayönü'ne geldiler.Fahrettin Altay, Sarayönü'ndeki buluşmayı şöyle anlatıyor:"Ben kendisine (Refet Bey'e) kuvvet göstererek iş yapmanın emin bir netice vermeyeceğini anlatmak istedimse de,söylediğim hususları tam bir alaka ile dinlemiyor ve bilgi edinmeden müstağni sabit bir hâl alan fikirlerindeki planı yürütmek isteyen soğuk bir tavır alıyordu. Kararını tatbikte ısrarcı olduğu anlaşılıyordu"(Altay, 1970, s.231).

Fahrettin Bey, Refet Bey'in Vali Suphi Bey ve Konya'dan gelen heyetle yaptığ1 konuşmayı şöyle naklediyor:"Millî harekete taraftar mısınızdiye sordu. Kim aksini söyleyebilirdi ki, herkes taraftarm cevabinı verdi. Bu cevaptan sonra Refet Bey -öyleyse şimdi hep beraber Ankara'ya gidelim ,Mustafa Kemal'e hürmet ve bağhllı̆̆ınzı fiilen gösteriniz.-Refet Bey bu sözlerle herkesi trene davet etti. Düzelen işlerin bozulacağ 1 düşüncesiyle yavaş yavaş bundan vazgeçmesini rica ettim. Başın sallayarak: Tabii siz de geleceksiniz cevabını verdi"(Altay, 1970, s. 231; Cebesoy, 1953, s. 341; Kişmir, 12 Nisan 1968).

Heyetle birlikte zoraki olarak Ankara'ya götürülen Fahrettin Bey gelişmelerden ciddi şekilde rahatsızdır. Bunu şu ifadelerle dile getirdi." Hacı Efendiler,bunun benim tarafimdan tertip edilmiş bir oyun olduğu kanâatine kapılarak bana güvenlerinin kalmadığım hissediyordum. Fakat Refet Bey'den farklı olduğumu göstermek daha fena olurdu" (Altay, 1970, s. 232).

Fahrettin Bey Konya eşrafına hissettirmek istemediklerini daha Ankara'da iken uygulamaya koydu. Bu olaydan sonra otoritesinin sarsıldığını ileri sürerek askerlik görevine devam etmekle birlikte Kolordu Komutanlığ görevinden istifa etti.Yerine o sırada Ankara'ya gelmiş olan Albay İsmet İnönü atandı (Cebesoy, 1953, s.342).

Heyeti 4 Nisan' da Refet Bey ve 12.Kolordu Komutanlı̆̆ına tayin edilen İsmet Bey'le birlikte Konya'ya döndü. $O$ günün akşamı Kolordu Karargâhında çoğunluğunu askerlerin oluşturduğu topluluğa bundan sonraki süreçte İstanbul'un değil Ankara'daki Mustafa Kemal Paşa'nın emrinde olacaklarını söylediler ve oradakilerden de buna uymaları talebinde bulundular. Hep bir ağızdan evet cevabı aldılar. Fahrettin Bey bu kabulün ardından yeni Kolordu Komutanı İsmet Bey'i takdim etti. 
Fahrettin Bey yeniden kolordu komutanlığına atanışını da şöyle anlatıyor. "Toplantıdan sonra İsmet Bey Bağdat Oteline yerleşti. Oradan Ankara'ya olan biteni anlatmıs.Bunun üzerine Mustafa Kemal benim tekrar kolordu komutanlığına tayin edildiğimi,kendileri ile birlikte Refet Bey ve maiyetinin de hemen Ankara'ya dönmelerini emretmiş"(Altay,1970, s.235).

İşler düzelmiş gibi görünüyordu. Fakat 2 Nisan 1920'de İstanbul'da Sadrazam Salih Paşa'nın görevinden ayrılı.Yerine 5 Nisan'da yeniden Damat Ferit Paşa kabinesi kuruldu. Ardından 13 Nisan'da Şeyhülislam DürrizadeAbdullah Efendi'nin Millî Mücadeleye katılanların dinen öldürülmelerinin uygun olacağı, yardımcı olanların ve hatta sempati duyanların da cezalandırılmaları gerektiği yönündeki meşhur fetvası yayımland1 (Uluğ, 1973, s. 201-203; Avanas, 1998, s. 109). Dinî hassasiyeti ile bilinen Konya'da yeniden işlerin karışmasına sebep oldu. Fahrettin Altay, Fetva'dan sonra Konya'nın görünümünü şöyle anlatıyor: "Konya hacı ve hocalar da esefle söyleyeyim ki bu yolda yürüyorlar fakat izlerini belli etmiyorlar"(Altay,1970, s.238).

O sırada Mektubi Kalem'inde görev yapan Kâzım Gürel ise hatıralarında her hacı hocayı suçlamak yerine daha açık ifadelerle: "İstanbul'da Millî Mücadele aleyhine verilen fetvalar Konya'ya kolaylkkla sokulmuştu. Zeynel Abidin Hoca'nın ${ }^{3}$ bu hususta büyük roller oynadığı söylenebilir. Hoca Nakşibendi tarikatının Halidiye koluna mensuptu.Gelen fetvalar yine bu kişiye bağlılığı ile bilinenler tarafından etrafa yayılmıştı.Bazı hocalar bunları halka gizli gizli okuyorlardı...Köyler bile bu fetvalarla dolmuştu dinî akideleri güçlü olan halkın üzerinde fetvaların etkisi büyük oldu"der(Gürel, 11 Eylül 1959, tefrika $5)$.

Konya'da Kuvayı Milliye teşkilatı güçlendikçe fetvadan güç alan Kuvayı Milliye karşıtları da gizlice teşkilatlanmaya başladı.Özellikle Hürriyet ve İtilaf Fırkası, İngiliz Muhipleri Cemiyeti mensupları ve sempatizanları Damat Ferit Paşa'nın hükümet olması ile Kuvayı Milliyecilerin söylediklerinin aksine Halife-Sultan'ın esir olmadığını özellikle köy ve kasabalarda yaymaya başladılar. Zeynel Abidin Hoca, Sait Molla gibi

\footnotetext{
3 - Zeynel Abidin Hoca 2.Meşrutiyet döneminde 2 defa Mebusan Meclisi'nde Konya Mebusu olarak bulunmuş, Mütareke döneminde ise Ayan Meclisi'nde aza sıfatıyla görev almıştı.
} 
siyasetçi din adamlarının politik, parasal ve menfaat desteği ile hacı-hocalar tarafından yürütülen bu propaganda özellikle kırsal alandaki halk üzerine büyük etki yaptı.

$\mathrm{Bu}$ örgütlenme ve propagandalardan endişe duyan başta Müdafaa-i Hukuk Reisi Sivaslı Ali Kemali olmak üzere bir grup vatansever Konyalı,Vali Suphi Bey, Kolordu Komutanı Fahrettin Bey, Polis Müdürü Fehmi Bey'in de katıldığ 4 Mayıs 1920 tarihli toplantıda bir an önce gerekli tedbirlerin alınması için talepte bulundular. Ancak Vali Suphi Bey giderek artan şikâyetler karşısında önlem alınmasını isteyenlere şu cevabı verdi:"Bunlarm asl yok hayal kuruyorsunuz. Böyle şeyleri uydurup size getirenler şehirde itilaf̧̧ı tanınmış olan birkaç adamı ezdirmek istiyorlar.Mesele budur.Ben böyle bir şey yapmam"(Gürel, 12 Eylül 1959 aynı tefrika; Altay, 1970, s.239-242) ${ }^{4}$.

Bununla birlikte Kolordu Komutanı Fahrettin Bey ve Müdafaa-i Hukukçuların gayretleri ile bazı önlemler alındı. Aynı günün gecesi yapılan baskınlarla Kuvayı Milliye aleyhine faaliyet gösteren bazı kişiler gözaltına alındı.Fahrettin Altay gözaltına alınanların anlattıklarını şöyle nakleder: "Salonda herkesin önünde yapılan soruşturmalarda köylüler açıkladılar ki, Konya etrafındaki bütün köylerde gönüllü teşkilatı yapılmış,yarın akşam her köyden silahlı atlılar Konya üzerine yürüyecekler ve orada büyükleri ne emir verirse onu yapacaklar. Fakat büyüklerin kim olduğunu bilmiyorlar..."(Altay, 1970, s. 241).

$\mathrm{Bu}$ toplantıyı takip eden bir kaç gün Konya'da ciddi bir olay yaşanmadı. Ancak olayların gelişiminde pasif davranan Vali Suphi Bey Ankara'ya çağrılarak uyarıldı(Altay, 1970, s.241).Geri döndüğünde Konya'da sıkıyönetim (Örfi İdare) ilan edildi.Fahrettin Altay Vali Vekilliğine getirildi.Tartışmaya konu olan 36 kişi Örfi İdare tarafından yargılanarak önemli bir kısmı tutuklandı(Altay, 1970, s.243).

Mustafa Kemal Paşa uzun süre tartışılan isyan girişiminin önlenmesinde Fahrettin Altay'ın gayretlerini şu sözlerle takdir eder:"Konya'da bulunan kumandan, malik olduğu kuvvetlerle cesurane hareket ederek asileri dağıtmaya ve önayak olanları tevkif ve takibe muvaffak oldu". (Nutuk, C. 2, s.450)

\footnotetext{
4 - Vali Suphi Bey bu gelişmeden kısa süre sonra Ankara Hükümeti tarafından görevden alındı ve yerine eski Van Valisi Haydar Bey atandı (Güngör, 1937 s.110).
} 
Ancak Mustafa Kemal Paşa alınan bütün tedbirlere rağmen Konya' da isyan tehlikesinin devam ettiği kanaatindeydi.Tehlikenin geçmediği Konya Milletvekili Arif Bey'in 17 Mayıs 1920'de Meclis'te yaptığı konuşmadaki "Konya'da halka yapılan fena telkinlerin önlenmesi ve gelecekte de bu tür fenalıklara meydan verilmemesi için, başka taraflara gönderildiği gibi Konya'ya da bir irşad heyetinin gönderilmesi" gerektiği talebinden de anlaşılmaktadır (TBMM: Z.C. C.1, Devre 1, 1959, s. 334-349). Meclis bu talebi 29 Mayıs 1920 tarihli kararıyla olumlu karşıladı (Tanrı̈ver, 1931, s. 173).Antalya Mebusu Hamdullah Suphi, Trabzon Mebusu Ali Şükrü, Konya Mebusu Refik Koraltan ve Milli Şair Mehmet Akif'ten oluşan bir heyet Haziran 1920'de Konya'ya geldi. Diğerlerinden birkaç gün önce Konya'ya gelen Hamdullah Suphi Haziranın ilk haftasında Cuma namazından sonra Kapı Camii' nde Konyalılara hitap ederek konuşmasını şu sözlere tamamladı: "Ta Selçuk günlerinden beri bir ilim ve fikir merkezi olan Konya'ya düşen vazife Anadolu mücadelesinde kendi büyük mazisine layık bir ruh ile rehber olmaktır. MilletMeclisi size bu düşüncelerinizi arzetmeye beni memur etti" (Seraslan, 1995, s. 95; Sarıhan, 1996, s. 113-114)5.

Mustafa Kemal Paşa'nın endişelerinde ne kadar haklı olduğu Mehmet Akif'in bu seyahatlerle ilgili olarak naklettiği bir hatırasından çok daha iyi anlaşılıyor. Akif'in bu hatıralarını yakın dostu Eşref Edip şöyle naklediyor:“Üstat Konyahlara nasihat etmiş,memleketin yıkılmak üzere olduğunu, bütün milletinbirleşerek Ankara'da kurulan hükümete yardım etmeleri gerektiği söylenince bir grup Konyalı: Biz Selçuk oğullarındanız. Bizden olmayan bir hükümetin yıkılmasindan bize ne?"(Semiz, 2000, s. 413-414)

Bununla birlikte irşat heyetinin çalışmaları belli ölçülerle başarılı oldu. Nitekim heyetin çalışmalarından sonra Tosun Bey'in başkanlığında bir heyet Ankara'ya gelip hükümet yetkilileri ile görüştüler ve"Ĕ̆ger daha evvel bu heyetinizi Konya'ya gönderseydiniz burada bir damla kan akmazdı"dediler (Baydar, 1968, s. 289).

\footnotetext{
5 - Oğlu, Akif'in Konya'ya Matbaacı Hüsamettin Efendi'nin daveti üzerine gittiğini yazar. (Millet Gazetesi, 18 Mart 1948, tefrika 111).
} 


\section{Atatürk'ün Milli Mücadele Yıllarında Konya'ya Gelişleri}

Atatürk milli mücadele yıllarında Batı Cephesinin ikmal merkezi olarak gördüğü Konya'yı 4 defa ziyaret etti. Aşağıda bu ziyaretleri değerlendirilecektir.

\subsection{Atatürk'ün Konya'ya İlk Gelişleri(1 - 4 Nisan 1922)}

Konya' da isyan teşebbüsünün yaşandığı ve Örfi İdare'nin bazı kişileri tutukladığı dönemden kısa bir süre sonra Öğüt Gazetesi, Mustafa Kemal Paşa'nın TBMM'den bir heyetle birlikte Afyon,Uşak ve Denizli Cephelerini teftiş ettikten sonra Konya' ya geleceğini duyurdu(Öğüt,31 Temmuz 1920; 4 Ağustos 1920). Bu haber Konya halkı arasında büyük heyecana yol açtı. İstasyondan şehre kadar ana cadde bayraklarla donatıldı. Mustafa Kemal Paşa ve arkadaşlarının geleceği 3 Ağustos 1920 sabahının erken saatlerinde halk istasyon yoluna dökülmüş, gar binasının çevresi hınca hınç dolmuştu. İstasyon rampasının sağ tarafında Sanayi Mektebi Müzikası, leyli(yatılı) İdadi, Askerî Rüştiye talebeleri, askerî birlikler ve polisler yerlerini almıştı. Rampanın sağ tarafında ise askerî ve mülki idarenin yanı sıra Şeyh Sünusi, Rum metropoliti,Ermeni ve Rumların önde gelenleri, eşraf ve diğer idari personel yer alıyordu(Babalık, 4 Ağustos 1920 No: 538; Evren, 1940, s. 5).

Mustafa Kemal Paşa ve beraberindeki heyet 3 Ağustos 1920 günü sabah saat 6 da istasyona gelir gelmez hazır bulunan bütün askerî erkân selam vaziyeti almış, Sanayi Mektebi bando ve müzikası da çalmaya başlamıştı.Tren İstasyonda durunca karşılama heyeti adına hazır bulunan Vali Haydar Bey, Mevki Komutanı Sabri, Müdafaa-i Hukuk Konya Merkez Heyeti Başkanı Müderris Sivaslı Ali Kemali.; Polis Müdürü Necip, Merkez Komutanı Şevki.; Şeyh Sünusi ${ }^{6}$ ve diğer üst düzey erkân vagon kapısının önüne gelerek heyeti karşıladılar(Babalık, 4 Ağustos 1920, No. 538). Gelen heyette Mustafa Kemal Paşa'dan başka Milli Müdafaa Vekili Fevzi Paşa (Çakmak),12.Kolordu Komutanı Fahrettin (Altay), Kurmay

\footnotetext{
6 - Şeyh Sünusi'nin Mustafa Kemal'e verdiği destek için bak. (Tanyol, 1981, s.135-137). Libya ve Cezayir'de yaygın Sünusi Tarikatı'nın Şeyhi 1.Dünya Savaşı sırasında Sultan Reşat'ın davetiyle Istanbul'a gelmiş. Sonraki yıllarda ülkenin çeşitli vilayetlerinde vatandaşlara telkinlerde bulunmuştur.
} 
Başkanı Şemsettin Bey, Antalya Milletvekili Rasih(Kaplan), İstanbul Milletvekili Hamdullah Suphi(Tanrı̈ver),Burdur Milletvekili Mehmet Akif ve bazı Konya Milletvekilleri vardı.Heyet tanışma merasiminin ardından hazırlanan fayton arabalarla valilik makamına geldiler.

Mustafa Kemal Paşa Valilikte şehrin ileri gelenleri ve heyetlerle görüşmeler yapmış ve ülkenin içinde bulunduğu durumu bütün açıklığı ile anlatmıştı.Akşamda Vali Haydar Bey'in konağında şerefine verilen ziyafette Müdafaa-i Hukuk Konya Merkezi Heyeti Reisi Ali Kemali'den 6 Haziran'daki Konya olayları ile ilgili bilgi aldı. Ali Kemali Hoca olaylara katılan ve tutuklananların büyük pişmanlık duyduklarını aslında bunların kandırılmış oldukları, eğer bunların affedilmeleri mümkün olursa Konya' da Ankara'ya karşı güvenin artacağını söyledi(Ertepınar, 1999, s.149).

Aslında Mustafa Kemal Paşa'ya benzer ricalar, Konya'ya gelmeden önce bazı Konya milletvekilleri tarafından da yapılmış ve Paşa da bu talepleri uygun bulmuştu. Nitekim bu gelişmeden bahseden Refik Koraltan"Paşa daha seyahate çıkmadan önce Adana, İçel, Nĭğdeve Antalya Milletvekillerinden bazıları ile eski İstanbul Eczanesinin karşısındaki bir evde Bozkır isyanından dolayı tutuklanmış olan vatandaşlarının affı için meclise bir kanun teklifi verilmesini görüşmüştü" der.Ancak bu teklifin verilmesi Koraltan ve Mehmet Vehbi Bey'in ricası ile Konya gezisinden sonraya ertelenmişti(Ertepınar, 1999, s.149).Bu yüzden Sivaslı Ali Kemali'nin de aynı kanatta olmasından memnun olmuş ve düşüncelerinin uygunluğunu teyit etmişti.

Aynı günü TBMM İkinci Başkanı Celalettin Arif Bey'e çekilen telgrafta "Konya'daki vaziyeti memnuniyet verici buldum.Halk ikna edilmiştir.Asilerin yalanlarına aldananlar hataların anlayarak,bunları telafi etmeye başlamışlardır. Konya olaylarından dolayı suçlu bulunun mahkeme tarafından tutuklanmış olanların affıyla asilerin amaçlarına ulaşmalarının engellenebileceğini düşünüyorum. Vali Beyefendi de benimle ayn fikirdedir. Cumartesi Mecliste toplantıyapılacağını biliyorum.Yalnızca bu konu hakkında karar vermek üzere Yüce Meclisin,beraberimdekilerle Konya'dan ayrilmadan önce af kararın vermesini rica ederim"der (TBMM Z.C., devre 1, C.3,s. 96; Önder, 1989, s. 7).

Telgrafın çekildiği sırada hükümet konağının önünde de ertesi gün yapılacak konuşma için kürsünün kurulması çalışmaları başlamıştı. Mustafa Kemal Paşa Vali Haydar Bey' in verdiği ziyafetin ardından kendisi için hazırlanmış olan Suriye asıllı İlyas Çaha'ya ait konağa (Bugünkü Atatürk 
Müzesi) çekildiler(Ertepınar, 1999, s.151).Diğer misafirler ise Bağdat Oteline yerleştiler(Evren, 1940, s.6).

Ertesi gün (4 Ağustos) sabah Mustafa Kemal Paşa, beraberinde Fevzi(Çakmak) Paşa ve bazı milletvekilleri ile halk üzerinde önemli tesiri olan ve Milli Mücadele taraftarlığı ile bilinen Şeyh Sünusi'yikaldığı evde ziyaret etti. Bir süre halkın irşadı ve daha önce yaşanan üzücü olayların bir daha yaşanmaması üzerine sohbet ettikten sonra önce Guraba Hastanesi (BugünküDevlet Hastanesi) ile Amerikan Hastanesi'ne gelerek burada bulunan yaralı ve hasta askerlerlegörüştü.Onlarıngönlünü aldı ve acil şifalar diledi (Arabac1, 1991, s. 13; Akandere, (t.y.), s. 10).Oradan Mekteb-i Sultaniye (Konya Lisesi) ye gidildi.Burada son sinifta okuyan Sadi Irmak'ın (Prof. Dr.- eski Başbakanlardan), Edebiyat Öğretmeni Hasan Rüştü Efendi tarafından hazırlanmış olan hoş geldiniz konuşması ile karşılandı (Irmak, 1982, s. 46; Yeni Konya, 28 Nisan 1975). Ardından da Hasan Rüştü, Mustafa Kemal Paşa için yazdığı şiiri okudu

Aynı gün öğleden sonra Mustafa Kemal ve beraberindekiler binlerce kişinin coşkulu alkışları ve tezahüratları arasında Hükümet Meydanı'na geldiler. Mustafa Kemal Paşa burada daha önce hazırlanmış olan kürsüye çıkarak ülkenin içinde bulunduğu durumu herkesin anlayabileceği bir üslupla halka anlattı. "Milli emellerimize ihanet eden kötü niyetliler, milletin iradesi ile cezalarım bulacak,hataların anlayacaklardır.Millet Kuvâ-yı Milliye ile hemfikirdir.Daima uyanık olmalıyı"dedikten sonra sözü dış düşmanlara getirerek "Düşmanlarımı şeref ve haysiyetimizi, namusumuzu istiyorlar. Bunları bizden aldıktan sonra kesin darbe kendiliğinden vurulmuş olacak.Bunu takdir ederek diyoruz ki istiklâl-i millimizi asla vermeyeceğiz. Binlerce senden beri istiklâl ve hürriyet saadetini yaşamış bir milletin istiklâl ve hürriyeti hiçbir zaman alınmaz. Kendi milletimize,kendi kudretimize istinaden mukaddes mücadelemize devam ediyoruz. Diyelim ki bütün batı âlemi bize düşmandır.Batılılar bizim kudretimizin maddeten tecellisini görmedikçe bize merhamet etmezler... Biz de tek millet ferdimiz kalsa da herhalde istiklalimizi vermeyeceğiz. Düşmanlarımızın

\footnotetext{
7- Arabacı ve Akandere okunan şiirin "Destan" adını taşıdığını yazar. Oysa Hasan Rüştü bu şiiri cumhuriyetin ilanından sonra yazmıştır. Bak.(Süslü, 1937, s.36-38).
} 
vatanımızın bağrında yaşamasına izin vermeyeceğiz"(Evren, 1940, s. 7; Önder, 1989 , s. $7-8)^{8}$.

Mustafa Kemal Paşa, Konyalı gençlere de şu hitabede bulundu:“Sizin her birinizin memleketin mukadderatın ilgilendiren konularda hassasiyetinizi takdir ediyoruz.Uzun asırlar istiklalini kendi milli şerefve mevcudiyetinin temeli kabul eden milletimiz bugün büyük bir tehlikenin eşiğindedir.Bizi bu tehlikeden kurtaracak ancak millî beraberliğimiz ve millet yolunda fedakârlı̆̆ımız olacaktır,sizlere karşı güvenimiz sonsuzdur.İstiklâl her zaman sizlerin omuzlarında yükselecektir"(Önder, 1989, s.8).

Mustafa Kemal Paşa konuşmasını tamamladıktan sonra bir süre daha halkla sohbet etti. Bir ara Mevlana Türbesini de ziyaret ederek Dergâh Şeyhi ve aynı zamanda Konya Milletvekili ve TBMM İkinci Başkanı olan Abdulhalim Çelebi ile görüştü.

$\mathrm{Bu}$ konuşma ve görüşmeler Konya halkının Kuvayı Milliye etrafında kenetlenmesinde önemli rol oynamıştı.

Mustafa Kemal Paşa 5 Ağustos 1920 sabahı bir kere daha Müdafaa-i Hukuk Cemiyeti Başkanı Sivaslı Ali Kemali Hoca ile görüştü. Bu görüşmede Hoca'ya Meclis İkinci Başkanı Celalettin ArifBey'den, Konya hadisesinde mahkûm olanların affedildiğine dair aldığ 1 telgrafı müjdelemiş ve affedilenlerin millî mücadelenin yanında yer almaları için telkinlerde bulunmasını rica etmişti ${ }^{9}$.

\subsection{Atatürk'ün Konya'ya İkinci Gelişleri (1 - 4 Nisan 1922)}

Atatürkikinci kez Konya'ya, Büyük Taarruz hazırlıklarının sürdüğü sirada cepheyi ziyaret ettikten sonra Akşehir'den trenle 1 Nisan 1922'de ikindiye doğru geldi. İstasyon Konya'daki çeşitli okul öğrencileri ve halk tarafından doldurulmuştu. Resmî karşılama heyetinde ise Vali Vekili

\footnotetext{
8 - Atatürk'ün bu nutkunun, Öğ̈̈t Gazetesinde yayınladığını söyleyen Refik Koraltan "Nutuk yazılırken Atatürk, benden birçok defa gazetenin bu sayısını istediler. Konya ve Kazalarında arattılar. Fakat maalesef sözü geçen gazete nüshası ele geçirilemedi" der (Ertepınar, 1999, s.153).

9 - Onun milli mücadele lehindeki gayretleri, küçük bir azınlık olan Ingiliz Muhipleri ve Hürriyet ve Itilaf Fırkası mensubu Damat Feritçileri çılgına çevrilmişti. Onlardan biri olan Konya Lisesi Öğretmeni ve Ali Kemali Efendi'nin komşusu Çumralı Emin Hoca'nın kışkırtması.; Zeynel Abidin Hocanın teşvik ve telkinleri.; bazı devlet erkânının bilgisi dâhilinde asker toplayan Delibaşı Mehmet'in isyan edeceği kendisine bildirilmesin rağmen vaktinden önlem almayan Vali Haydar Bey'in ihmali ve Ali Kemali Hoca'nın Milli Mücadele'nin ilk şehitleri arasında yer almasına sebep oldu (Evren, 1944,s.10-11).
} 
Mustafa Abdülhalik(Renda),Ahz-1 Asker Heyeti Reisi Rüştü Paşa,Menzil Müfettişi Kâzım(Dirik),Demiryolları Genel Müdürü Behiç (Erkin), Mevlâna Dergâhı Postnişin Vekili AdilÇelebi (Postnişin Milletvekili ve TBMM İkinci Başkanı Abdulhalim Çelebi' dir,Belediye Başkanı M.Muhlis (Koner), Konya Milletvekilleri Hadımlı Mehmet Vehbi ve Kâzım Hüsnü, Samsun Millet Vekili Nafiz Bey,askerî ve mülki erkân yer alıyordu.

Trenden inen Mustafa Kemal Paşa ve beraberindeki Rusya Şuralar Cumhuriyeti Ankara Büyükelçisi Aralof;Azerbaycan Cumhuriyeti Büyükelçisi İbrahim Abilof; Rusya ve Azerbaycan Cumhuriyeti Askeri Ataşeleri Zıvanaryof ve Ali Abilof 'a, Vali Vekili Abdulhalik Bey, beraberindeki üst düzey erkânı tek tek takdim etti(Önder,1989, s.10-11; Evren, 1940, s.8-9; Güven, 2006, s. 58 - 60; Kişmir, 17 Mayıs 1972).Ardından büyük bir coşku ile bugünkü Atatürk Müzesine doğru yürüyüşe geçildi.Bu coşkulu yürüyüş esnasında kendilerine zarar verilebileceğinden çekinen Aralof, bir ara Atatürk'ün kulağına eğilerek" Paşam arabalara binsek daha iyi olmaz mı?" dedi (Arıburnu, 1976, s. 3210). Atatürk misafirlerinin endişelerini de dikkate alarak Feridiye Karakolu'nun önünde beraberindekilerle birlikte arabaya binerek konaklayacakları yere kadar geldiler.

Halk da evin önünde misafirlere coşkulu sevinç gösterisi yapmaya başladı. Coşkulu kalabalığın sevgi gösterisini karşılıksız bırakmayan Atatürk ve beraberindekiler balkona çıkarak halkı selamladılar. Ardından halk sessizce dağıldı (Evren, 1940, s. 9; Aralof, 1967, s.104-105).

Akşam Belediye Başkanı Muhlis (Koner) kendilerine bir ziyafet verdi.O gece iki medrese de ziyaret edildi. Aralof,ziyaret edilen medrese ile ilgili hatıralarını anlatırken şu ifadelere yer veriyor:"Hemen hepsi de gencecik mollalar medresenin avlusunda dizilmişlerdi.Bunların yanında geniş cübbeli,beyaz sarıklı hocalar da vard.. Hepsi de yerlere kadar eğilerek Mustafa Kemal Paşa'yı selamliyorlardı. Bunların başı, Mustafa Kemal Paşa'dan medreselerin sayısının arttırılmasını ve medrese öğrencilerinin askere alınmamasını rica etti.

Hoca konuşurken Mustafa Kemal'in kendisini tuttuğu belli oluyordu.Ama medrese öğrencilerinin askere alınmamaları söz konusu olunca artık kendisini tutamadı ve yüksek sesle -ne o dedi.Yoksa sizin için medrese, Yunanlılar mağlup

\footnotetext{
10 - Aralof'un Türkçeye çevrilen hatıralarında bu ifade yer almıyor.
} 
etmekten, halkı zulümden kurtarmaktan daha mı değerlidir?Millet kan içinde yüzerken, halkın en iyi çocukları cephelerde dövüşüp,yurt için canların feda ederken, siz burada, genç, sapasağlam delikanlıları besiye çekmişsiniz. Bu asalakların askere alınmaları için hemen yarn emir vereceğim.- Hocalar Mustafa Kemal'in bu çıkışı karşısında kıpkırmızı kesildiler"(Aralof, 1967, s. 105-106; Kişmir, 18 Mayıs 1972).

Ertesi gün (2 Nisan 1922) sabah saat 9'da Atatürk ve beraberindekiler yine halk arasındaydılar.Etraf tamamen bayraklarla donatılmıştı.Polis ve jandarmanın açtı̆̆ yoldan heyet önce hükümet konağını, ardından da belediyeyi ziyaret ettiler. Daha sonra Millî Mücadele gazilerinin de bulunduğu Hilâl-i Ahmer Askerî Hastanesine gidildi. Gaziler tek tek ziyaret edilerek çeşitli ikramlarda bulunuldu. Heyet oradan önce İmalat-1 Harbiye Fabrikası ve Atölyesine sonra Topçu Okulu ve Askeri Lise' ye geldi. Okula dersler devam ederken gidilmişti. Hesap, Fransızca, Coğrafya veTarih derslerine katıldılar. Atatürk her girilen sınıfta öğrencilere sorular sordu. Doğru cevaplar aldıkça memnuniyetini belli ediyordu.

Oradan Dar' ül- Eytam (Yetimler Yurdu)'a gidilerek kız ve erkek yetim çocuklar ziyaret edildi. Kendilerini şiirler okuyarak ve küçük bir temsil vererek karşılayan çocuklara hediyeler verildi. Bu arada Aralof ve Abilof yurdu ayrı ayrı yüzer lira bağışta bulundular(Önder, 1989, s.13).

Öğlenden sonra Atatürk ve beraberindekiler Dar'ülMuallimat'ı (Kız Öğretmen Okulu) ziyaret ettiler. Orada Millî Eğitim Müdürü M.Ferit(Uğur) tarafından karşılanarak salona alındılar. Karşılıklı konuşmalar, şiir ve marşlar okunmasından sonra misafirlere çay ikram edildi.(Aralof, 1967, s.110).Saat 16.00 sularında bugün Hâkimiyet-i Milliye olarak bilinen Samanpazarı çevresindeki ilkokul ziyaret edildi.Atatürk burada bir öğrenciye "Şu anda Türkiye'nin sahibi kimdir?"diye bir soru sordu. Çocuk alışkanlıktan "Padişah" dedi. Bir anlık sessizlikten sonra Atatürk öğretmenlere "çocuklara gereksiz ezberler yaptırmak yerine Türkiye'nin bugünkü gerçek durumunu öğretiniz"dedi. (Aralof, 1967, s. 107).

Bu ziyaretin ardından ilkokula çok yakın bir iş hanında eğitim-öğretim yapan Nalbant Okulundaki diploma törenine katıldılar. Atatürk'le beraber törene katılan Rus Elçisi Aralof Nalbant Okulu ile ilgili şu bilgiyi veriyor: "Okul binası nal biçiminde idi. Okulun içinde birkaç nalbantlık atölyesi kurulmuştu. Okul öğrencilerinin çoğunluğunu cepheden getirilmiş erler teşkil 
ediyordu. Öğrenciler arasında Yunanlılarm işgal ettikleri bölgelerden getirilmiş öksüz çocuklarda vardı. Okulun duvarları şu dövizlerle donatılmıştı. Çalışanları Tanrı Sever, Çalışmak İbadettir..."(Aralof, 1967, s.107).

Atatürk ve beraberindekiler kendileri için ayrılan yere oturduktan sonra okul müdürü, okulun önemi hakkında bir konuşma yaparak, okulun özellikle ordunun süvari birlikleri için bilgili, tecrübeli nalbantlar yetiştirdiğini ve ilk etapta otuz öğrenci mezun ettiklerini söyledi. İkinci konuşmayı yapan Konya Menzil Müfettişi Kâzım (Dirik) Ordu Levazım Grubu tarafından kurulan okulun tarihçesini anlattıktan sonra okulu şereflendiren misafirlere teşekkür etti(Aralof, 1967, s.107; Önder, 1989, s.14-15; Güven, 2012, s. 210 - 212).

Kâzım Bey'in konuşmasından sonra kürsüye gelen Atatürk:"Bugün bir sanat müessesesinin içinde bulunuyoruz. Bu müessesenin ikinci mahsulünü orduya takdim ettiğini gördüğümden cidden bahtiyarm. Bu müessesenin vücuda getirilmesine hizmet edenlere hassaten teşekkür eder ve onları takdirat ile tebrik ederim"dedi. (Söylev ve Demeçler, 1989, C. 2, s.34 - 36). Daha sonra okul birincisi ve ikincisine birer saat hediye etti.

Son konuşmayı yapan Aralof ise konuşmasında"Nalbant Okulunun, bağımsızlı̆̆ın işleyen ve İtilaf Devletlerine boyun eğmeyen yeni Türkiye'yi sembolize ettiğini"söyledi(Aralof, 1967, s.108; Kişmir, 19 Mayıs 1972).

Diploma töreninden sonra heyet yeniden misafir edildikleri konağa geri döndü.Konuklar 3 Nisan 1922 günüVali Vekili Abdülhalik (Renda), Ahz-1 Asker Reisi Rüştü Paşa, Menzil Müfettişi Kâzım (Dirik) ve elçilerle Mevlana Dergâhını ziyaret ettiler. Konukları dergâh meydanında, çelebi ve dervişler karşılamış ve türbe ziyareti boyunca refakat etmişlerdi. Ziyaretin sonunda Vilayet İdare Meclisi Üyesi tarihçi Hamdizade Abdülkadir' in (Erdoğan)verdiği bilgileri dinlediler(Aralof, 1967, s.110 - 111; Önder, 1989, s.18; Güven, 2012, s. 212).

\subsection{Atatürk'ün Konya'ya Üçüncü Gelişleri (24-27 Temmuz 1922)}

Atatürk'ün Konya'ya üçüncü gelişleri Büyük Taarruz hazırlıklarının yapıldığ1 döneme rastlar. Bilindiği gibi Batı Cephesi Karargâhı Akşehir'dedir. Atatürk, Genelkurmay Başkanı Fevzi Çakmak ve Batı Cephesi Komutanı İsmet İnönü ile hazırlanan taarruz planının ayrıntılarını görüşmeye karar verdiler. Ancak bu görüşmeyi dikkatlerden 
uzak tutmak için o sırada Adana'da bulunan ve Atatürk'le görüşmek isteyen İngiliz Generali Townshend'in talebi ön plana çıkarıldı ve Temmuz'da Konya'da görüşmek için randevu verildi. Bu gelişme üzerine General Townshend 23 Temmuz sabahı Konya'ya geldi ve Vali Vekili Abdulhalik Bey tarafından törenle karşılandı (Hâkimiyeti Milliye, 25 Temmuz 1338).

Atatürk, 24 Temmuz'da Başbakan Rauf Bey'e gönderdiği yazıda Konya'ya gideceğini şöyle bildirmişti: "Cepheden şimdiye kadar elde edilen bilgiler ve yakından yapılan incelemelere göre düşmanın gerçek amacı tespit edilememiştir. Durumun tespiti için Cephe Komutanliğ başvurmuştur. Ben bir iki gün sonra General Townshend ile görüşmek üzere Konya'ya gidiyorum"(Harp Tarihi Vesikaları Dergisi, 1994, s.6-7).

Oysa Atatürk Nutuk'ta "23 Temmuz 1922 akşamı Garp (Batı) Cephesi Karargahı'nın bulunduğu Akşehir'e gittim. Harekât hakkında Erkânı Harbiye-i Umumiye Reisi ile görüşmeyi münasip gördüm. 24 Temmuz'da daKonya'ya gittim" diyerek önce asıl amaç için Akşehir'e daha sonra da İngiliz Generali ile görüşmek için Konya'ya gittiğini belirtiyor(Atatürk, Nutuk, C. 2, s.671672).

Atatürk'ün Konya'ya geleceği önceden bilindiği için başta gar çevresi olmak üzere şehir bayraklarla donatılmıştı. Karşılama heyeti içinde bir askerî birlik, Dâr'ü'l-Eytam (öksüzler yurdu) öğrencileri.; esnaf temsilcileri ve çok sayıda vatandaşın yanı sıra Vali Vekili Kadı Mehmet Emin Bey, bazı Konya Milletvekilleri.;Ahz-i Asker Heyeti Reisi Rüştü Paşa, İngiliz Generali Townshand, Belediye Başkanı M.Muhlis (Koner) ve diğer askerî ve mülki temsilciler vardı (Babalık, 27 Temmuz 1922; Öğüt 26 Temmuz 1922; Hâkimiyeti Milliye, 26 Temmuz 1922; Önder, 1989, s.20-21; Güven, 2012, 279 - 282).

Atatürk, trenden indikten sonra, önce Askeri birliği selamlamış, karşılama heyeti ile görüşmüş ve ardından Öksüzler Yurdu öğrencilerinin arasına girmiş, bu sırada Sanayi Mektebi Mızıkası eşliğinde okunan İstiklâl Marşı'na eşlik etmişti. Bu merasimin ardından Atatürk General Townshend'le birlikte İstasyon Caddesinde kendileri için hazırlanan köşke geçtiler ve görüşmelerini yaptılar. Atatürk25 Temmuz 1922'de Başbakan Rauf Bey'e çektiği telgrafta bu görüşmenin içeriğinin Anadolu'nun Yunan işgalinden kurtarılması ve genel barışın sağlanması 
ile ilgili olduğunu belirtti (Atatürk'ün Milli Dış Politikası, 1992; Belge No 79, s.438-443; Akandere, Güven, 2002, s.22-24).

Görüşmelerin ardından 27 Temmuz'da Konya'dan ayrılarak yeniden Akşehir'e gelmişti. 27-28 Temmuz gecesi Paşalarla yaptıkları görüşmelerden sonra tespit edilen plan gereğince taarruz için 15 Ağustos'a kadar bütün hazırlıkların bitirilmesine karar verdiler(Nutuk, C. 2, s. 672).

\section{4. Atatürk'ün Konya'ya Dördüncü Gelişleri (20 Temmuz 1922)}

Atatürk'ün Konya'ya dördüncü kez gelişleri, üçüncü gelişlerinde alt yapısı hazırlanan Büyük Taarruz'un uygulamaya konulması içindir. Bundan dolayı bu gezi büyük bir gizlilik içinde gerçekleşti. O kadar ki Bakanlar Kurulu dışında kalan milletvekillerinin bile bu geziden haberleri olmadı. Bu yüzden bazı muhaliflerin yaptıkları olumsuz propagandalarla aslında kendi amaçları dışında Milli mücadeleye hizmet ettiklerini Atatürk Nutuk' ta şu cümlelerle açılar: "Muhalifler ordunun tefessüh (bozulma) ettiğinden, kıpırdayacak halde olmadı̆̆ından, böyle müphemiyet (gizlilik) içinde intizarın (bekleme) felakete sebep olacağından ibaret propagandalarma hiz vermişlerdi. Gerçi Mecliste bu telâkkinin (anlayışın) yaptığı akisler zaten düşmanlardan çok gizlemek istediğim harekât nokta-i nazarından faydalı idi"( Nutuk, C.2, s. 673).

Bu gizlilik içinde Atatürk Ankara'dan Konya'ya gelişini de şöyle açıklar: "Hareketimi pek mahdut(az) birkaç kişiden başka Ankara'dan gizledim. Benim gaybubet (yok olmak) edeceğimi bilenler, burada imişim gibi davranacaklardr. Hatta benim Çankaya'da çay ziyafeti verdiğimi de gazetelerde ilan edeceklerdi... ${ }^{11}$ Trenle hareket etmedim. Bir gece (19 Ağustos gecesi) otomobil ile Tuz çölü(gölü) üzerinden Konya'ya gittim. Konya'ya vasıl olur olmaz telgrafhaneyi kontrol altına aldirarak Konya'da bulunduğumun da hiçbir tarafa bildirilmemesini temin ettim" (Nutuk, C. 2, s. 673).

Yaklaşık dokuz saat süren zorlu bir yolculuktan sonra geç saatlerde Başyaveri Salih Bozok ve Yaver Muzaffer'le (Kılıç) birlikte Konya'ya gelen Atatürk burada Selanik'ten beri yakın arkadaşı olan ve o dönemde

\footnotetext{
${ }^{11} 20$ Ağustos 1922 tarihli Hâkimiyeti Milliye gazetesinin ilk sayfasında şu ilan yer almıştı. "Gazi Paşa Hazretleri 21 Ağustos Pazartesi günü kössklerinde ricali siyasiye ye bir çay ziyafeti verecekler". Ayrıca bak. (Özalp, 1971, s. 234; Gürel 2007, s. 282).
} 
Konya'da Anadolu-Bağdat Demiryolları Genel Müdürü olan Behiç Erkin'in evine gelerek misafir olmuşlardı. Erkin hatıralarında o geceyi anlatırken şöyle der: "Yemekten sonra Konya'daki evimde istirahat ederken aşağıdan bir gürültü duydum, kalktım o anda Gazi Paşa'yı karşımda buldum. Aman kimse duymasın, ben gizli geldim, burada kalacağım- dediler. Bu gizli seyahatin bir manası olduğunu sezdim. O gün baş başa konuşurken söz siyasi ve askerî duruma geldi. Gazi, Bana -düşman hakkında aldığım malumatı yan yana getirdim, buna göre artık bu badireye son vermenin zaman geldiğine hükmettimdedi. Ertesi gün öğleden sonra hazırlattığım hususi bir katarla Akşehir'e hareket buyurdular"(Erkin, 1955, s. 602; Önder, 1989, s. 24).

20 Ağustos'ta Akşehir'e gelen Atatürk burada komutanlarla bir toplantı yaptı. Fahrettin Altay bu toplantı için şu bilgiyi veriyor: "Bu toplantıda kendisi (Atatürk), Kurmay Başkam ile Cephe Kumandanı, 1. ve 2. Ordu Kumandanları ve SüvariKolordusu Kumandanı sıfatı ile beni (Fahrettin Altay) bulundurdu. Yalnız 2. Ordu Kumandanı ordunun henüz kâfi kuvveti olmadığından taarruzda muvaffakiyet olmazsa memleketin müdafaasinn tehlikeye düşeceğini bildirdi"(Altay, 1970, s. 329). Başkomutan ise saldırının yapılacağını ve ona hazırlanmamız gerektiğini açık bir dille ifade etti(Altay, 1970, s.329).

\section{Sonuç}

Atatürk, Milli Mücadele yıllarında stratejik öneminden dolayı, daha sonraki yıllarda ise gelişen olaylara karşı Türkiye genelini en iyi yansıtan yerlerden biri olarak gördüğü için, her önemli sosyal ya da siyasi olayın ardından Konya'yagelmiş, şehirde halkla iç içe olarak halkın nabzını tutmuştur. Atatürk'ün Konya'ya gelişleri ile siyasi ve sosyal olayları yan yana getirdiğimiz zaman bu hakikat daha iyi anlaşılmaktır. Örneğin Milli Mücadele yıllarındaki ilk gelişleri 3 Ağustos 1920, İstanbul Hükümeti'nin Konya'da Teâli İslâm Cemiyeti üyesi din adamı Zeynelabidin Efendi aracılığı ile Delibaş Mehmet İsyanının hazırlanmaya başladığı döneme; 4'üncü gelişleri Büyük Taarruz 'un hazırlık aşmasının tamamlanmak üzere olduğu 20 Temmuz 1922 tarihine olur.

Atatürk, Konya'ya gelişlerinde sosyal ve politik gözlemi ön planda tutmakla beraber özellikle eğitim kurumları ile de yakından ilgilenmiştir. 
Konya'da bir günden fazla kaldıkları her ziyarette çeşitli eğitim kurumlarını gezerek öğrenciler, öğretmen kadrosu ve öğretim kalitesi ile yakından ilgilenmiştir. Bu durum Atatürk'ün eğitime verdiği önemin büyüklügüünü göstermektedir.

Bütün bunlar bir yana Atatürk'ün derin ve duygusal bir Konya sevgisi de vardır. Duygusal sevgisinin köklerinde atalarının Konya'dan Selanik'e göç etmesinin önemli yeri vardır. Atatürk, atalarının Konya'dan göç ettiğini dil çalışmaları dolayısıyla zaman zaman Atatürk'ün sofrasında bulunma onuruna erişmiş olan dönemin Konya milletvekillerinden Naim Hazım Onat'aşu cümlelerle anlatmıştır: "Konya benim dedelerimin öz vatanıdır. Onlar Rumeli'ye Anadolu'dan göçmüşlerdir"(Önder, 1989, s.1).Aynı şekilde Atatürk'e yakınlığı ile bilinen tarihçi Enver Behnan Şapolyoda Atatürk'ün baba tarafından dedelerinin Kırmızı Hafız boyundan olduğunu yazar (Şapolyo, 1944, s.15).Bu boy Karaman bölgesinden Rumeli'ne göç ettirilen Yörüklerdendir (Göksel, 1988, s.5).

Atatürk'ü derin ve samimi duygularla Konya'yı ziyaret etmesini sağlayan unsurlardan biri de hiç şüphesiz Mevlâna'nın fikirleri ve Mevlevilerin Milli Mücadeleye verdikleri destekten kaynaklanmaktadır.. $\mathrm{Bu}$ sevgiden dolayı Atatürk Tekke ve Zaviyelerin kapatılması kanunundan sonra Mevlâna Dergâhını "Âsar-ı Âtika Müzesi" olarak halkın ziyaretine açık kalmasını sağlamıştır.

\section{Kaynakça}

\section{Resmi Yayınlar}

Atatürk'ün Milli Dış Politikası, (1992). (Milli Mücadele Dönemine Ait 100 Belge) 1919 - 1923, C. 1, Kültür Bakanlı̆̆1 Yay., Ankara, Belge No. 79.

Harp Tarihi Vesikaları Dergisi, (1994). S. 59, Belge 1354, Başbakanlık Devlet Arşivleri Genel Müdürlüğü Cumhuriyet Arşivi yay., Ankara.

Konya Vilayet Salnamesi, (1317). Hicri.

TBMM: Zabit Ceridesi, (1959). C. 1, Devre 1, 3. bas., Ankara.

TBMM Zabit Ceridesi, (1959). C. 3, Devre 1, 3. bas., Ankara.

\section{Dergi ve Gazeteler}

Babalık, (Konya Gazetesi), 26 Ağustos 1331 (1915).

, 6 Temmuz 1336 (1920). 
- 4 A Agustos 1336 (1920).

27 Temmuz 1338 (1922).

Hâkimiyeti Milliye, 25 Temmuz 1338 (1922).

,26 Temmuz 1338 (1922).

Millet Gazetesi, 18 Mart 1948, tefrika 111.

Öğ̈̈t, 31 Temmuz 1336 (1920).

$\longrightarrow 4$ Ağustos 1336 (1920).

-26 Temmuz 1338 (1922).

Yeni Konya, 9 Mayıs 1972.

28 Nisan 1975.

\section{Telif ve Tetkik Eserler, Makaleler}

Altay, F., (1970). On Yil Savaş ve Sonrası, İnsel Yay., İstanbul.

Akandere, O., (t.y.). Atatürk'ün Konya' yı Ziyaretleri ve İlk Ziyaretleri İle İlgili Gözlemleri, Atatürk ve Konya, Selçuk Ünv. Yay, Konya, s. 710.

Akandere, O. ve Güven, C., (2002). İngiliz Generali Townshend'in Anadolu Seyahati ve Mustafa Kemal Paşa ile Konya'da Yaptığ1 Görüşme, S.Ü. Atatürk Illkeleri ve Inkılâp Tarihi Araştırma ve Uygulama Merkezi Ata Dergisi, S. 9, Konya, s. 22 - 24.

Arabacı, C., (1991). Milli Mücadele Dönemi Konya Öğretmenleri, Kültür Sarayı yay, Konya.

Aralof, S. İ., (1967). Bir Sovyet Diplomatı'nın Türkiye Hatıraları, Çev: Ali Ediz, Burçak yay, İstanbul.

Arıburnu, K., (1976). Atatürk den Anılar, Türkiye İş Bankası yay., Ankara. Atalay, A., (1997). Milli Mücadelede Konya Kuvayı Milliyecileri, C.1, Damla Ofset, Konya.

Atatürk, M.K., (1973). Nutuk, C. 2, Ankara.

Atatürk'ün Söylev ve Demeçleri (1989). C: 2, Atatürk Araştırma Merkezi Yay., Ankara.

Atatürk'ün Tamim Telgraf ve Beyannameleri, (1991). C. 4, Atatürk Araştırma Merkezi yay., Ankara.

Avanas, A., (T.y.). Konya Müdafaa-yı Hukuk Cemiyeti'nin Kuruluşu ve Çalışmaları, Atatürk ve Konya, Selçuk Ünv. Yay. Konya.

Avanas, A., (1998). Milli Mücadele'de Konya, Atatürk Araştırma Merkezi yay., Ankara. 
Baydar, M., (1968). Hamdullah Suphi Tanriöver ve Anıları. Menteş Kitabevi, İstanbul.

Bıyıklığlu, T., (1969), Atatürk Anadolu'da (1919-1921), Ankara.

Cebesoy, A. F., (1953) Milli Mücadele Hatıraları, Vatan Neşriyat, İstanbul.

Coşar, Ö. S., (1919). İstiklâl Harbi Gazetesi, Yeni İstanbul yay., 27 Eylül, S.119.

Coşar, Ö. S., (1964). Milli Mücadele Basını, Gazeteciler Cemiyeti yay. İstanbul.

Erdeha, K., (1975). Milli Mücadele Vilayetler ve Valililer, Remzi Kitapevi, İstanbul.

Erkin, B. (1955). Atatürk'ün Selanik'te Askerlik Hayatına Ait Hatıralar, Ankara.

Ertepınar, C., (1999). Bir Politikacının Anıları - Refik Koraltan, Hacettepe Taş yay. Ankara.

Evren, A., (1940). Atatürk'ün Konya'ya Gelişleri, Babalık Matbaası, Konya.

Göksel, B., (1988). Atatürk'ün Soy Kütü̆̆̈̈̈ Üzerine Bir Araştırma, Ankara.

Göztepe, T. M., (1969). Osmanoğulları'nın Son Padişahı Vahdettin Mütareke Gayyasında, Sebil Yay., İstanbul.

Güngör, B., (1937). Harp Hatıraları, Kanaat Kitabevi, İstanbul.

Gürel, K.,(1956). Konya' da Milli Mücadele Hatıraları, Yeni Konya, (tefrika 5) 11 Eylül.

Gürel, T., (2007). Atatürk'ün Yaveri Cevat Abbas Gürer, Gürer yay, 4. bas., İstanbul.

Gürel, Z., (1989). Kurtuluş Savaşında Demiryolculuk,T.T. Kurumu bas., Ankara.

Güven, Cemal, (2006), Mustafa Kemal Paşanın Büyük Taarruz Öncesinde Sovyet Rus ve Azerbaycan Elçileri İle Cephe ve Cephe Gerisi Gezisi (Sivrihisar - Çay- Akşehir- Ilgın - Konya), Yeni Ipek Yolu Konya Ticaret Odası Dergisi, Nisan, Sayı: 218, Konya.

Güven, Cemal, (2012), Millî Mücadele'de Mustafa Kemal Paşa'nın Yabancılarla Temas ve Görüşmeleri (Asker, Siyasî Temsilci ve Gazeteciler), Eğitim Yayınevi, Konya.

Irmak, S., (1982). Atatürk'ten Anilar, Ankara.

Karpat, K., (1985). OttomanPopulation (1830-1914) DemographicAndSocialCharacteristic. Wisconsin- London.

Kişmir, C., (1968). Sivaslı Ali Kemali, Yeni Konya, 09 Nisan. 
Kişmir, C., (1968). Refet Bele'nin Konyalılara Oynadığı Oyun, Yeni Konya, 12 Nisan.

Kişmir, C., (1972). Mustafa Kemal ve Rus Elçisinin Konya Gezisi 2.,Yeni Konya, 18 Mayıs.

Kişmir, C., (1972). Mustafa Kemal ve Rus Elçisinin Konya Gezisi 3., Yeni Konya, 19 Mayıs.

Kişmir, C., (1972). Konya Kız İlk Öğretmen Okulundaki Konuşmaları, Yeni Konya, 2 Temmuz.

Kutay, C., (1977). İstiklâl Savaşı'nın Maneviyat Ordusu, C. 2, Yelken Mat., İstanbul.

Nasrallah, B. M., Rüştü, K. M., Eşref, M. M., (1325). Mükemmel Mufassal Atlas, Şirketi Mektebiye Mat., İstanbul.

Önder, M., (1954). Bilgin Sivash Ali Kemâlı̂, Yeni Kitap Basımevi, Konya.

Önder, M., (1955). Milli Mücadelede Konya 1., Delibaş Hadisesi, Konya.

Önder, M., (1986). Milli Mücadelenin Yanına ve Safına Öğüt Gazetesi., Güven Mat., Ankara.

Özalp, K., (1971). Milli Mücadele (1919 - 1922) C. 1, Türk Tarh Kurumu Yay., Ankara.

Sarıhan, Z., (1996). Mehmet Akif, Kaynak yay, İstanbul.

Semiz, Y., (2000). Milli Mücadele ve Mehmet Akif, S. Ü Türkiyat Arş. Enst. Dergisi, S. 7, Konya s. 413 - 414.

Seraslan, H., (1995). Hamdullah Suphi Tanriöver, Türk Kültürü Arş. Enst. Yay., Ankara.

Sıfır, M., (1940). Konya İsyanı'nın iç yüzü, Yeni Sabah, 29 Kanunisani (Ocak).

Süslü, M. Y., (1937). Ermenekli Hasan Rüş̧ü Hayat ve Eserleri, Yeni Kitap ve Basımevi, Konya.

Şapolyo, E. B., (1944). Kemal Atatürk ve Milli Mücadele Tarihi, Kanaat Kitapevi, Ankara.

Tanrı̈̈ver, H. S., (1931). Dă̆g Yolu 2. Kitap, Türk Ocakları yay., Ankara.

Tanyol, C., (1981). Atatürk ve Halkçılık, Türkiye İş Bankası yay., Ankara. Uluğ, N., (1973). Siyasi Yönleriyle Kurtuluş Savaşı, Milliyet yay., İstanbul. 


\section{Kaynakça Bilgisi / Citation Information}

Semiz, Y.\& Toplu, G. (2017). Milli Mücadele Döneminde Konya ve Atatürk,OPUS - Uluslararası Toplum Araştırmaları Dergisi, 7(12),254283. 